\author{
dr inż. Marcin ŁUSZCZYK \\ Wydział Ekonomii i Zarządzania, Politechnika Opolska \\ e-mail: m.luszczyk@po.opole.pl
}

DOI: $10.15290 /$ ose.2016.02.80.03

\title{
RELACJE PARADYGMATU ROZWOJU TRWALEGO Z KATEGORIĄ JAKOŚCI ŻYCIA
}

\begin{abstract}
Streszczenie
Mimo nasilającej się krytyki PKB, brak alternatywnej metody pomiaru dobrobytu społecznego powoduje, że miernik obejmujący tylko sferę gospodarczą nadal pozostaje kluczowym parametrem ocen i porównań międzynarodowych. Wypracowanie i upowszechnienie uniwersalnej metodyki pomiaru jakości życia stanowi zatem poważne wyzwanie skierowane w stronę środowiska akademickiego i praktyków.

Zdaniem autora, silne, wzajemne relacje nowego paradygmatu rozwoju trwałego z kategoria jakości życia wynikają bezpośrednio z samej jego definicji. Po pierwsze, na podstawie Raportu Brundtland i Deklaracji z Rio można stwierdzić, że rozwój trwały to taki rozwój, który zapewnia zaspokojenie potrzeb i osiagnięcie wysokiej jakości życia współczesnemu społeczeństwu bez uszczerbku dla możliwości realizacji potrzeb przyszłych pokoleń. Po drugie, idea rozwoju trwałego oparta na ładzie zintegrowanym ściśle odpowiada holistycznemu charakterowi jakości życia. Można więc uznać, że realizacja zasad rozwoju trwałego jest tożsama z dążeniami do wysokiej jakości życia, a wskaźniki cząstkowe opisujące rozwój trwały można z powodzeniem wykorzystać do określenia jakości życia.
\end{abstract}

Słowa kluczowe: rozwój trwały, jakość życia

\section{PARADIGM OF SUSTAINABLE DEVELOPMENT AND QUALITY OF LIFE}

\section{Summary}

Despite rising criticism of using GDP as a measure of social welfare, lack of an alternative method causes this purely economic indicator to remain the key parameter for assessments and international comparisons. Developing a universal methodology for measuring the quality of life is thus a serious challenge for both academics and practitioners.

According to the author, the strong relationship between the new development paradigm and the quality of life stems directly from the very definition of sustainable development. Firstly, on the basis of the Brundtland Report and the Rio Declaration, it can be concluded that sustainable development is a development that provides satisfaction, fulfils needs and achieves a high quality of life in modern society without prejudice to the possibility of meeting the needs of future generations. Secondly, the idea of sustainable development based on integrated governance closely corresponds to the holistic nature of the quality of life. It can therefore be concluded that the implementation of the principles of sustainable development is synonymous with aspirations to a high quality of life and partial indicators describing sustainable development can successfully be used to gauge the quality of life.

Key words: sustainable development, quality of life

JEL: Q01, I31 


\section{Wstęp}

W reakcji na nasilającą się krytykę PKB jako miernika dobrobytu społecznego usilnie poszukuje się alternatywnych sposobów pomiaru jakości życia. Wypracowanie i upowszechnienie uniwersalnej metodologii pomiaru jakości życia wyeliminowałoby, nierealne do utrzymania w długiej perspektywie, koncepcje wzrostu gospodarczego, które przynoszą maksymalizację konsumpcji jedynie w krótkim okresie. Brak alternatywnej metody pomiaru dobrobytu społecznego sprawia z kolei, że miernik obejmujący tylko sferę gospodarczą nadal pozostaje kluczowym parametrem ocen i porównań międzynarodowych.

Celem opracowania jest analiza zależności między paradygmatem rozwoju trwałego a kategoria jakości życia. W zamiarze autora wyniki przeprowadzonych analiz maja stanowić krok w kierunku rozwiązania problemu badawczego: jak łączyć pomiar wskaźnikowy jakości życia z pomiarem nowego paradygmatu rozwoju [Borys, 2014, s. 18-19]?

\section{Krótka ocena PKB}

Miernik wartości wytworzonych w kraju dóbr i usług - produkt krajowy brutto (PKB) został opracowany w 1947 roku w ramach przygotowanego wówczas Systemu Rachunków Narodowych (SNA), [Measurement..., 1947]. Pierwsze krytyczne uwagi pod adresem PKB pojawiły się już na etapie jego wdrażania. Kontrowersje dotyczyły przede wszystkim braku dostatecznej poprawności w wewnętrznej konstrukcji. Wtedy również uznano PKB za niewłaściwy miernik dobrobytu [Borys, 2014, s. 5]. Negatywne oceny PKB pojawiały się także w latach siedemdziesiątych XX wieku i później. Ich źródłem były przede wszystkim, odbiegające od oczekiwań, efekty ilościowego wzrostu gospodarczego w krajach rozwijających się [Szarfenberg, 2011, s. 93].

Krytyka PKB jako miernika dobrobytu społecznego nasiliła się wraz z ostatnim kryzysem finansowym i gospodarczym. Wśród wielu publikacji na ten temat wymienić należy m.in.: Komunikat Komisji Europejskiej [Komunikat..., 2009], opracowanie zespołu pod kierunkiem Roberta Costanzy [Costanza, Hart, Posner, Talberth, 2009] oraz Raport Komisji do spraw Pomiaru Wydajności Ekonomicznej i Posteppu Społecznego działającej pod przewodnictwem noblistów: Josepha E. Stiglitza (laureata Nagrody Nobla z 2001 roku), Amartya Sena (laureata Nagrody Nobla z 1998 roku) i Jean-Paula Fitoussiego [Stiglitz, Sen, Fitoussi, 2013], a który zawiera problemy związane z wykorzystaniem PKB i uwagi na temat pomiaru dobrobytu społecznego. Zainteresowanie również budzą wcześniejsze prace nawet polskich ekonomistów, w tym publikacje Tomasza Żylicza, który nie tylko omówił kontrowersje związane z PKB, lecz zarazem zaproponował konkretne rozwiązania istniejących dylematów przez ,zazielenienie” tradycyjnego PKB [Żylicz, 2010, s. 79]. Z reguły główne zastrzeżenia i kontrowersje związane ze stosowaniem PKB dotyczą następujących kwestii: wliczania do PKB wydatków niewpływających na wzrost dobrobytu, wyłączania $z$ rachunków narodowych usług świadczonych w gospodarstwach domowych, nieuwzględniania prac wolontariuszy, braku korelacji wartości PKB ze stanem środowiska naturalnego, ignorowania nierówności społecznych, pomijania 
zróżnicowania cen dóbr i usług w różnych krajach oraz uwzględniania działań niezaspokajających rzeczywistych potrzeb społeczeństwa [Łuszczyk, 2013, s. 73-74].

Podsumowanie krytycznych uwag pod adresem PKB przedstawiła Frances Stewart, stwierdzając, że wৃrost PKB nie uwzglednia tego, jak dochód jest dystrybuowany pomiędzy różne grupy ludności, nie uwzolędnia dóbr publicznych, zatrudnienia - czyli tego wszystkiego, co ma fundamentalne znaczenie dla poprawy jakości sycia [Szarfenberg, 2011, s. 94]. Tomasz Żylicz dowodził, z kolei, że PKB «liczy to, co sie nie liczy, a nie liczy tego, co sie liczyy». To znaczy PKB uw zglednia to, co nie jest dla nas ważne, a nie uwzglednia tego, co ważne [亡்ylicz, 2014, s. 277].

Aby zwięźle przedstawić argumenty ,za” produktem krajowym brutto, warto nawiązać do wypowiedzi Josepha E. Stiglitza, który napisał: PKB nie jest sam z siebie zły. Jest on w niewtaściwy sposób wykorzystywany [Brandle, 2009]. Rzeczywiście, PKB, mimo pewnych ułomności, generalnie sprawdza się jako miernik aktywności gospodarczej. Sposób jego liczenia jest jednoznacznie określony w systemie rachunków narodowych [Rozporzqdzenie..., 2013], a jego syntetyczny charakter ułatwia porównywanie efektów gospodarczych w skali krajowej i międzynarodowej. Jak zauważył Tomasz Żylicz, PKB sprawdzał się tak dobrze, że zarówno ekonomiści, jak i zuykli ludzie zaczlli go traktowá́ jako ogólny miernik driatalności gospodarczej i dobrobytu [Żylicz, 2007, s. 94]. Ponadto, wytworzone dobra i usługi, uwzględniane przecież w rachunkach narodowych, zaspokajają co najmniej podstawowe potrzeby członków społeczeństwa. Zdaniem Abrahama Maslowa, to właśnie stopień realizacji potrzeb związanych z zaspokojeniem pragnienia i głodu, posiadanie odpowiednich warunków mieszkaniowych, odzieży i możliwości prokreacji w najwyższym stopniu wpływają na ocenę jakości życia [Maslow, 1943]. Również wśród socjologów panuje opinia, że jakość życia odzuierciedla sposób i stopień zaspokojenia różnych potrzeb czlowieka (...) [Papuć, 2011, s. 144].

Przedstawione, pozytywne opinie nie oznaczaja jednak akceptacji dla PKB jako miernika dobrobytu społecznego. Bogactwo materialne stanowi bowiem kategorię podrzędną względem jakości życia, ponieważ dla człowieka miara bogactwa będzie zakres potržeb, k.tóre dzieki bogactwu bedzie mógt zaspokoić [Simonde de Sismondi, 1955, s. 66].

Krytyczna ocena PKB jako miernika dobrobytu społecznego skłoniła badaczy z wielu ośrodków naukowych do podejmowania prób opracowania alternatywnych mierników. Mimo to, wypracowanie uniwersalnego sposobu pomiaru dobrobytu i jakości życia jest trudne i wciąż spotyka się z rozbieżnymi stanowiskami naukowców. Problem tkwi w różnicach: kulturowych, światopoglądowych, ekonomicznych i religijnych, które utrudniają osiagnięcie konsensusu. Badania te polegaja przede wszystkim na: dokonaniu korekty dotychczasowych mierników, w tym PKB, przygotowaniu wskaźników mierzących bezpośrednio dobrobyt społeczny i jakość życia, opracowaniu syntetycznego miernika lub wykorzystaniu zestawu wskaźników ${ }^{1}$.

Na przykład Organizacja Narodów Zjednoczonych od 1990 roku systematycznie publikuje raporty na temat stanu rozwoju społeczeństw na świecie. Zawarty w nich wskaźnik rozwoju społecznego (Human Development Index - HDI) dla poszczególnych państw jest zaliczany obecnie do najbardziej popularnych mierników jakości życia. Podstawa jego opracowania są:

1 Dotychczasowe prace w zakresie wskaźników dobrobytu społecznego szerzej omówili m.in.: Jerzy Śleszyński [Śleszyński, 2011, s. 82-97] i autor niniejszego artykułu [Łuszczyk, 2013, s. 113-140]. 
- przeciętna długość życia,

- osiagnięcia edukacyjne społeczeństwa,

- $\quad$ PNB na mieszkańca w USD, liczony według parytetu siły nabywczej.

Interesującym rozwiązaniem jest wskaźnik trwałego dobrobytu ekonomicznego (Index of Sustainable Economic Welfare - ISEW), zaproponowany w 1989 roku przez Hermana Edwarda Daly'ego oraz Johna Cobba. Podstawę obliczeń wskaźnika dobrobytu stanowi poziom indywidualnych wydatków konsumpcyjnych. Wartość ta korygowana jest in plus o pracę wykonywaną w gospodarstwie domowym i usługi dóbr trwałego użytku, a dobra publiczne. Wartość wskaźnika jest pomniejszana równocześnie o koszty zanieczyszczenia środowiska, a także zmian klimatycznych i degradacji warstwy ozonowej, uszczuplenia zasobów naturalnych oraz dodatkowe koszty wynikające z urbanizacji. Badania gospodarki amerykańskiej wykazały, że w latach 1951-1986 PKB na mieszkańca wzrósł dwukrotnie, a wskaźnik ISEW jedynie o 20\%, co oznacza, że wzrost gospodarczy tylko do pewnego stopnia wpływa na jakość życia [Daly, Cobb, 1989].

Warto również zwrócić uwagę na wskaźnik rzeczywistego postępu (Genuine Progress Indicator-GPI) stanowiący rozwinięcie wskaźnika trwałego dobrobytu ekonomicznego. Przy jego opracowaniu uwzględniono szersza gamę czynników modyfikujących pierwotny poziom konsumpcji, m.in.: wartość realizowanych prac społecznych, koszty rozpadu rodzin, przestępstwa i bezrobocie. Istotnym problemem w oszacowaniu wartości wskaźnika stała się wycena elementów nieposiadających ceny rynkowej. Z tego też powodu, mimo trwających już od 1995 roku prac, tylko nieliczne kraje względnie regiony dysponują własnymi szacunkami tego wskaźnika [Śleszyński, 2011, s. 92]. Porównanie omawianego wskaźnika z PKB na mieszkańca potwierdziło wcześniejsze przypuszczenia, że do początku lat siedemdziesiątych XX wieku wzrost PKB rzeczywiście powodował poprawę jakości życia. Dalszy intensywny wzrost gospodarczy nie przynosił już zauważalnej poprawy sytuacji społeczeństwa amerykańskiego.

\section{Kontrowersje definicyjne związane z jakością życia}

Na tle, krytykowanego wprawdzie, ale precyzyjnie zdefiniowanego, syntetycznego i rozpowszechnionego już PKB zupełnie odmiennie prezentują się kwestie dotyczące oceny jakości życia. Nie tylko nie ma pełnej zgody w sprawie definicji jakości życia, ale również występują poważne kontrowersje dotyczące pomiaru jakości życia. Jedną z przyczyn tego stanu rzeczy jest fakt, że zainteresowanie zagadnieniem jakości życia jeszcze w latach siedemdziesiątych XX wieku było stosunkowo niewielkie. Współcześnie pojęcie jakości życia jest bardzo modne wśród polityków, a nawet stanowi przedmiot badań naukowych i budzi żywe zainteresowanie w społeczeństwie. Niestety, postępowi techniki i wzrostowi gospodarczemu nie towarzyszy dziś adekwatna poprawa jakości życia [Ostasiewicz, 2013, s. 229].

Jakość jest kategorią złożoną, odmienną znaczeniowo w porównaniu z kategorią ilości. Jakość życia jest pochodną subiektywne odbieranych bodźców - wrażeń zmysłowych, 
ponadto zależy od obiektywnych warunków życia. Jest ona zwykle opisana za pomocą wielu cech. W badaniach nad jakością życia wyróżnia się dwa jej wymiary (rysunek 1.):

- deskryptywny - określający obszar zainteresowań badaczy;

- $\quad$ komparatywny - pozwalający na ocenę poziomu jakości życia.

RYSUNEK 1. Relacje pomiędzy deskryptywną a komparatywną oraz subiektywną i obiektywną jakością życia

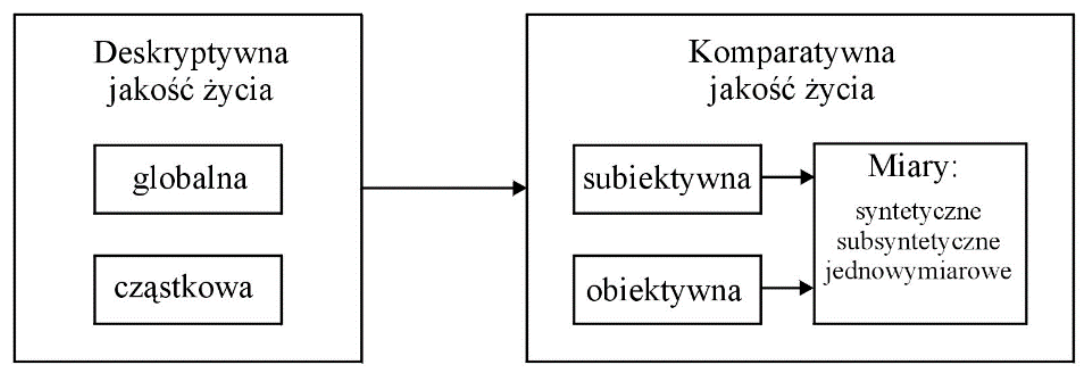

Źródło: [Borys, 2001, s. 81].

W zależności od: zainteresowań i subiektywnych odczuć autorów, ich postaw, przekonań, zakresu prowadzonych przez nich badań oraz warunków, w których żyja, można znaleźć w literaturze wiele definicji jakości życia. Warto zwrócić uwagę na niektóre z nich, wyróżnione poniżej.

1. Jakosí życia to godne warunki życia w spoteczeństwie. Należq do nich dobra materialne, poczucie równości i sprawiedliwości, równe szanse $w$ edukacji $i$ zatrudnieniu, sprawiedliwy podziat dochodu, humanizacja pracy itp. [Soziologie-Lexikon, 1991, s. 364].

2. Jakość życia sprowadza się do ogólnie pojetego szczéścia [Noll, 2000, s. 7].

3. Jakość zycia jest wartościq odczumana, ksztattujaca sie pod wplywem trzech diviedzin cymilizacyjnych: kulturowej, prayrodniczej i gospodarczej [Poskrobko, 1998, s. 81].

4. Jakość życia to subiek.tywna ocena sytuacji życiowej, uwzgledniajaca okerélona hierarchie wartości [Papuć, 2011, s. 143].

5. Jakość życia jest z̧biorem czynników okeréslajacych obiektywne warunki zycia i subiektywnie odczuwany dobrobyt [Glatzer, 2006, s. 12].

6. Jakość życia stanowi wielowymiarowa ocene okoliczności życiowych. Należq do nich wskaźniki określajace obiektywne warunki bytowe oraz subiektywne çynniki, obejmujace fizyczna, psychologiczna społeczna $i$ duchowa sfere życia [Galloway, Bell, Hamilton, Scullion, 2006, s. 116].

Łatwo dostrzec, że w wymienionych definicjach stosuje się takie pojęcia, jak: szczęście, dobrobyt, godne warunki życia, zaspokojenie potrzeb, na przykład w zakresie edukacji i zatrudnienia itp. Jest w nich również obecne odwołanie do obiektywnych i subiektywnych czynników oraz wielowymiarowości, z czego wynika, że jakość życia należy rozpatrywać w ujęciu holistycznym. 
Papież w swojej najnowszej encyklice pt.: Laudato Si zwrócił również uwagę na potrzebę holistycznego podejścia do rozwiązywania współczesnych problemów cywilizacyjnych, zauważył: Fundamentalne znaczenie ma poszukiwanie rozwiazań integralnych, uw agledniajacych interakcje systemów pryyrodniczych miedzy soba oraz z systemami spotecznymi. Nie ma dwóch odrebnych krysysów, jeden środowiskowy, a drugi spoteczny, ale istnieje jeden żożony kryyzys spoleczno-ekologiczny [Franciszek, 2015, s. 139]. Słuszność podejścia holistycznego do pomiaru jakości życia potwierdza łacińska sentencja: Bonum ex integra causa, malum ex quocumque defectu, mówiąca o tym, że dobro wynika z całości, zło z jakiejkolwiek usterki. Jakość życia, jak głosi społeczna nauka Kościoła Katolickiego, tworzą także wartości pozamaterialne (subiektywnie oceniana jakość życia). Duchowość chrześcijańska dowodzi papież Franciszek - proponuje alternatywny sposób rozumienia jakości życia i zachęca do życia zdolnego do głębokiej radości i unikania obsesji na tle konsumpcji, stąd:

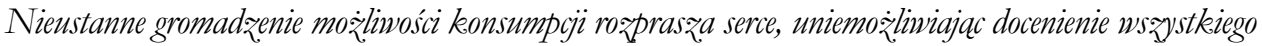
$i$ każdej chwili. Natomiast stawanie w pogodzie ducha przed tym, co istnieje, choćby tego by to niewiele, otwiera nam znacznie wiekesze szanse na zrozumienie $i$ spetnienie osobiste [Franciszek, 2015, s. 222].

W ocenie stopnia realizacji jakości życia zachodzi jednocześnie konieczność wyboru systemu wartości - punktu odniesienia. Bez ustalenia podstawy aksjologicznej wszelkie oceny i porównania byłyby wadliwe. Te same zjawiska mogą być bowiem inaczej oceniane w zależności od przyjętego systemu wartości. Na przykład nadmierne bogacenie się jednostki, powodujące jednak wzrost nierówności społecznych, dla egocentryka jest czymś pozytywnym, natomiast umiarkowany antropocentryk takie działanie oceni zdecydowanie negatywnie. Przyjęty system aksjologiczny i szerokość społecznie akceptowanego pola etycznego decyduja zatem o sposobie relatywizacji jakości życia (rysunek 2.).

RYSUNEK 2. Klasyfikacja systemów wartości według kryterium szerokości pola etycznego

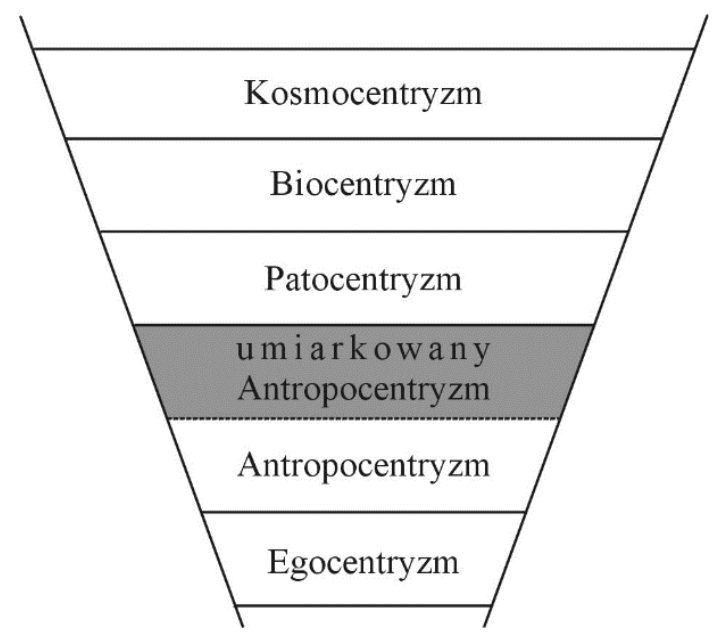

Źródło: [Borys, 2004, s. 56]. 
Przypisanie kategorii jakości życia wyłącznie tej części społeczeństwa, z którą się utożsamiamy - przyjęcie egocentrycznego systemu wartości - stoi w sprzeczności z zasadą sprawiedliwości międzypokoleniowej będącej jednym z filarów wielu paradygmatów rozwoju, w tym koncepcji rozwoju trwałego [Borys, 2005, s. 33]. Wypaczony antropocentryzm (egocentryzm) stwarza przestrzeń dla takiego stylu życia. Współczesny, praktyczny relatywizm moralny jest jeszcze bardziej niebezpieczny od relatywizmu doktrynalnego. Człowiek stawiający siebie w centrum, daje priorytet temu, co jest doraźnie wygodne. Wówczas całe otoczenie staje się względne [Franciszek, 2015, s. 122].

Dopiero umiarkowany antropocentryzm uznaje podmiotowość etyczną każdego człowieka, również przyszłych pokoleń, niezależnie od: rasy, wyznania wieku i pozycji społecznej [Borys, 2005, s. 33]. Z perspektywy umiarkowanego (słabego) antropocentryzmu środowisko naturalne jest czynnikiem mającym istotny wpływ na kształtowanie wewnętrznego, duchowego świata człowieka. Oferuje ono człowiekowi zarówno dobra konsumpcyjno-materialne, jak i estetyczno-duchowe. Środowisko jest dobrem pozwalającym przetrwać człowiekowi nie tylko w sensie biologicznym, ale również zachować i rozwijać ludzką kulturę. Funkcjonujący w oderwaniu od środowiska naturalnego człowiek naraża swoją biologiczną i duchową egzystencję. Jak zauważył Hołub: Staby antropocentryzm daje podstawy do krytycznego spojrzenia na system wartości, który jest zdominowany przez. czysto eksploatacyjne traktowanie natury [Hołub, 2005, s. 58-59].

Pewne kontrowersje może budzić dalsze poszerzanie podmiotowości etycznej, co postulują zwolennicy ekologii głębokiej. Zgodnie z tym poglądem, wszystkie istoty w biosferze mają równe prawo do życia i samospełnienia się. Jednak równość biocentryczna niesie ze sobą negatywne konsekwencje dla człowieka, bowiem traci on swoja nadrzędną pozycję względem innych gatunków i form życia [Hołub, 2009, s. 132]. Przyjęcie stanowiska o równości wszystkich istot utrudnia, a nawet uniemożliwia sformułowanie i realizacje rzeczywistych koncepcji rozwoju. Teoria rozwoju jest bowiem ściśle powiązana z celem istnienia i działania człowieka, który jest najwyższą wartością w świecie przyrody. Pominięcie człowieka w proponowanych koncepcjach rozwoju powoduje, że z założenia są one sprzeczne z prawidłowo zdefiniowanym celem i sensem istnienia człowieka, prowadzą do nieefektywnego wykorzystania zasobów oraz w długim okresie nie zapewnią rozwoju [Piontek, 2007, s. 57-59].

\section{Rozwój trwały jako dążenie do wysokiej jakości życia społeczeństwa}

Zasada trwałości (zrównoważenia) rozwoju została sformułowana po raz pierwszy w 1713 roku przez Hansa Carla von Carlowitza. Otóż, arystokrata stwierdził, że zasoby leśne są największym skarbem Saksonii, a prawidłowa gospodarka polega na sadzeniu nowych drzew w miejsce już wyciętych. Tego rodzaju działalność: wymaga najwiekeszego kunsz̨tu, nauki, pilności i praygotowania tutejszej ziemi, aby ustanowić $i$ utrwalic taki sposób uprany drzew, w której istnieje trwałe $i$ zrównoważone u̇̀tkowanie zasobów, poniewazjest to rzecz niezbedna, bez której kraj nie może istniéc [Carlowitz, 2009, s. 65]. Wprawdzie osiemnastowieczna reguła odnosiła się wyłącznie do gospodarki leśnej, ale należy odnotować fakt, że już wówczas 
zwrócono uwagę na potrzebę trwałego i zrównoważonego gospodarowania dobrami (niem. beständige und nachbaltende Nutrung).

Ponad 250 lat później, w 1968 roku, za sprawą sekretarza generalnego ONZ, U. Thanta, dyskusja dotycząca kierunków dalszego rozwoju społeczno-gospodarczego świata nabrała nowego wymiaru. Problem nie dotoczył już tylko gospodarki leśnej, lecz relacji pomiędzy gospodarką a środowiskiem. Podejście zaprezentowane w latach sześćdziesiątych XX wieku jest obecnie kojarzone z ekorozwojem (ecodevelopment) - wąskim ujęciem współcześnie rozumianego rozwoju trwałego. W rezolucji Zgromadzenia Ogólnego ONZ pt.: Problemy środowiska ludzkiego zwrócono uwagę na konieczność podjęcia wysiłków na rzecz: ochrony środowiska, zagrożeń dla rozwoju cywilizacji wynikających z braku powiązania zaawansowanych technologii z wymogami środowiska naturalnego, erozji gleb, bezplanowej urbanizacji, rosnącego ryzyka wyginięcia niektórych gatunków flory i fauny [Problems..., 1969, s. 2].

Podczas konferencji, nazwanej Szczytem Ziemi, w Sztokholmie w 1972 roku ponownie wyrażono potrzebę uwzględnienia ochrony środowiska w dalszym rozwoju społeczno-gospodarczym świata. Odrzucono wtedy tradycyjną koncepcję rozwoju gospodarczego, pojmowanego wyłącznie jako wzrost dochodu narodowego, na rzecz działań zmierzających do realizacji konkretnych celów społecznych. Podkreślono, że człowiek ma podstawowe prawo do wolności, równouprawnienia i należytych warunków życia oraz ponosi obowiązek ochrony środowiska dla obecnych i przyszłych pokoleń. Ponadto, w raporcie stwierdzono, że rozwój społeczno-gospodarczy jest niezbędny do zapewnienia sprzyjających warunków i poprawy jakości życia człowieka. Jednak rozwój ten nie może odbywać się kosztem środowiska naturalnego [Report..., 1972, s. 4].

Ważnym etapem w doprecyzowaniu i zrozumieniu pojęcia trwałego wzrostu była publikacja raportu przygotowanego pod przewodnictwem Gro Harlem Brundtland, przez Światową Komisję do spraw Środowiska i Rozwoju [Our Common..., 1987]. W raporcie stwierdzono, że rozwój trwały (Sustainable Development) to taki rozwój, który zapewnia realizację potrzeb obecnego pokolenia bez wywierania negatywnego wpływu na możliwości zaspokojenia potrzeb przyszłych pokoleń. Od czasu publikacji raportu Brundtland rozwój trwały stał się pojęciem wielowymiarowym, rozpatrywanym w układzie społeczeństwo - środowisko przyrodnicze - gospodarka i ściśle kojarzonym z jakością życia.

Aby nie mnożyć kolejnych ${ }^{2}$, nie zawsze w pełni trafnych, objaśnień rozwoju trwałego warto powrócić do oryginalnego tekstu z raportu Brundtland:

Zrównoważony rozwój to rozwój, który zaspokaja potrzeby obecnego pokolenia bez.pozbawiania mo:̀liwości prazyszlych pokolen do zaspokajania ich potrzeb. Odwotuje sie on do dwóch kluczowych koncepcï:

- zaspokajania potrzeb, w szczególności, majacych priorytetowe znaczenie, podstawowych potrzeb ubogich;

- ograniczeń natożonych przez stan technologii i organizacji spotecznej na zdolność środowiska do zaspokojenia obecnych i praysztych potrzeb [Our Common..., 1987, s. 24].

\footnotetext{
${ }^{2}$ Już w 2012 roku Piotr Jeżowski wskazał ponad 100 interpretacji rozwoju trwałego [Jeżowski, 2012, s. 101]. Szerzej problemy terminologiczne związane z rozwojem trwałym przedstawił m.in. Kazimierz Górka [Górka, 2010, s. 10-21].
} 
Podjętym tu rozważaniom służy odwołanie się w definicji. Po pierwsze, do koncepcji potrzeb - tej samej, na której bazuje wielu autorów definicji jakości życia, a po drugie, do koncepcji sprawiedliwości społecznej. W związku z tym, za rozwój trwały należy rozumieć taki rozwój, który zakłada równowage między gospodarką a stanem ekosystemów w celu realizacji dążeń społeczeństwa do wysokiej jakości życia [Papuziński, 2006, s. 28]. Paradygmat rozwoju trwałego opiera się na komparatywnej interpretacji kategorii jakości życia i pozwala na sformułowanie pojęć pochodnych jakości życia - obiektywnej i subiektywnej jakości życia [Kusterka-Jefmańska, 2010, s. 116]. Jak zauważył Famielec: Zaweżanie $i$ adresowanie idei zrównoważonego rozwoju tylko do środowiska i jego ochrony czyni tej zasadzie wiecej szkód niżpożtków. Rozwój trwaty wymaga zarówno zachowania czystego środowiska naturalnego, jak $i$ zapewnienia społeczeństwu satysfakcjonujacego dobrobyitu [Famielec, 2009, s. 36 i 44].

W raporcie Brundtland wielokrotnie podkreślano wpływ wielu czynników na jakość życia, w tym: środowiskowych, społecznych i gospodarczych. W dokumencie stwierdzono między innymi, że istniejące dysproporcje dochodowe w społeczeństwach sa przyczyna zróżnicowania jakości życia dziś i zdolności społeczeństw do poprawy jakości życia w przyszłości. Ponadto, realizacja ludzkich potrzeb i dążeń stanowi główne cele rozwojowe. Niestety, potrzeby te, szczególnie w krajach rozwijających się, nie są spełniane. Rozwój trwały wymaga zrealizowania co najmniej podstawowych potrzeb, aby społeczeństwa mogły zaspokoić swoje aspiracje związane z wyższą jakością życia. Zwrócono również uwagę na: pozbawioną ładu urbanizację, ubóstwo, nadmierne wylesianie i dynamiczny rozwój przemysłu. Czynniki te negatywnie wpływają nie tylko na jakość życia społeczeństw, ale i stan środowiska naturalnego. Zdaniem autorów raportu, włączenie zasad rozwoju trwałego do globalnych norm etycznych i ich wypełnianie jest niezbędne do zapewnienia wysokiej jakości życia na Ziemi.

Pięć lat po publikacji raportu Brundtland, podczas Konferencji Narodów Zjednoczonych w sprawie Środowiska i Rozwoju w Rio de Janeiro, w 1992 roku ponownie zwrócono uwagę na pogarszający się stan środowiska przyrodniczego i zagrożenie dla jakości życia na Ziemi. Uczestnicy konferencji zdecydowanie zaapelowali w sprawie ostatecznej rezygnacji z dotychczasowego rozwoju gospodarczego, ocenianego wyłącznie przez pryzmat wzrostu poziomu dochodów, na rzecz rozwoju trwałego. W deklaracji uwzględniono konieczność: eliminacji ubóstwa, zmniejszenia różnic w poziomie życia i dążenia do zaspokojenia potrzeb społeczeństw jako niezbędnego wymogu realizacji rozwoju trwałego. $Z$ analizy treści dokumentu wynika, że pojęcia rozwoju trwałego i jakości życia są wzajemnie spójne, a ich zapewnienie wymaga realizacji tych samych zadań, zatem: Aby osiagnać rozwój trwaty i wy ższa jakość życia dla wszystkich ludzi, państwa powinny zredukować badź wyeliminować nie zrównoważone systemy produkcji lub konsumpcji oraz promować odpowiednia polityke demograficzna [Rio Declaration..., 1993, s. 4].

Idee wdrażania rozwoju trwałego przyjęła również Unia Europejska. W przyjętej w 2001 roku strategii zapisano, że rozwój zrównoważony oferuje Unii Europejskiej pozytywna dtugoterminowa wizje spoteczeństwa, które jest zamożniejsze i bardziej sprawiedliwe, $i$ które obiecuje czystsze, bezpieczniejsze $i$ zdrowsze środowisko - społeczeństwa, które zapewnia lepsza jakość życia nam, naszym diqeciom i wnukom [Komunikeat..., 2001, s. 2]. Wśród czynników wpływających na stopień realizacji rozwoju trwałego jako tożsame zostały wówczas wymienione determinanty 
jakości życia, m.in.: postępujące zmiany klimatyczne, ubóstwo, niestabilność finansów publicznych i systemów emerytalnych, utrata bioróżnorodności, zagęszczenie transportu i nadmierna urbanizacja [Komunikat..., 2001, s. 3-4].

Szczyt Ziemi w Rio de Janeiro z 1992 roku nie pozostał bez echa. Dekadę później w Johannesburgu odbyła się konferencja, której przewodnim tematem były zmiany dokonujące się w środowisku przyrodniczym. Stwierdzono wówczas, że rožóój trwały to droga do poprany jakości życia bez nadmiernej eksploatacii surowcón naturalmych. Pełne wdrożenie zasad rozwoju trwałego wymaga zróżnicowanych działań w poszczególnych regionach świata w trzech priorytetowych obszarach, takich jak: wzrost gospodarczy i równomierny podział dochodu, ochrona zasobów naturalnych i środowiska oraz rozwój społeczny [Johannesburg..., 2001, s. 4].

We wspomnianej już encyklice papież Franciszek omówił zagadnienia związane z problemami środowiska przyrodniczego i rozwojem trwałym silnie powiazanym z jakością życia, tj.: poważnie zanieczyszczone środowisko, globalne ocieplenie, wyczerpywanie się zasobów naturalnych, spadek bioróżnorodności, ubóstwo i nierówności społeczne oraz negatywne skutki dynamicznego rozwoju przemysłu. Obserwowane powszechnie zmiany, po pierwsze, wyraźnie kontrastują z naturalna powolnościq ewolugij biologicznej, po drugie zaś, ich celem nie zawsze jest rozwój trwały zorientowany na wspólne dobro. Tego rodzaju niekorzystne dla człowieka i środowiska procesy prowadzą do degradacji świata i obniżenia jakości życia oraz budzą poważny niepokój o przyszłość ludzkości [Franciszek, 2015, s. 18].

O ile bezpośrednio po publikacji raportu Brundtland rozwój trwały był postrzegany w układzie społeczno-środowiskowo-gospodarczym, o tyle współcześnie, w najszerszym wymiarze, nowy paradygmat jest zwykle kojarzony z ładem zintegrowanym. Obejmuje on sześć kategorii/wymiarów, tj.: gospodarczy, społeczny, ekologiczny, przestrzenny, polityczno-instytucjonalny oraz etyczno-moralny. Rozważania w zakresie rozwoju trwałego sa prowadzone nawet $\mathrm{z}$ uwzględnieniem kategorii czasu [Czaja, 2011, s. 59-74], a w ostatnim okresie pojawia się dodatkowo kategoria kulturalna [Kiełczewski, 2013, s. 135-143; Górka, Łuszczyk, 2014, s. 25-32]. Często niedostrzegany, niekiedy kontrowersyjny etyczno-moralny wymiar rozwoju trwałego wynika z samej definicji. Przecież podstawą rozwoju trwałego jest koncepcja sprawiedliwości społecznej, która odwołuje się również do wartości pozamaterialnych - duchowych. Etyka współczesnego społeczeństwa bowiem musi opierać się na szacunku dla człowieka i respektować prawa przyszłych pokoleń, które także będą chciały z godnością realizować swoje potrzeby. W tym znaczeniu, działania współczesnego pokolenia decydują o życiu i rozwoju przyszłych społeczeństw. Współczesne pokolenia są zatem odpowiedzialne za zachowanie stanu środowiska i jego zdolności do zaspokajania potrzeb przyszłych pokoleń. Obowiązek ten ma charakter wyłącznie moralny, gdyż nieistniejące jeszcze pokolenia nie posiadają odpowiednich narzędzi ani możliwości egzekwowania swoich praw [Jonas, 1996, s. 57].

Ostatnim elementem paradygmatu rozwoju trwałego jest system wartości, stanowiący fundament i spoiwo nowego wzorca rozwoju. Prowadzone dotąd badania pozwalają 
uznać za słuszną tezę, że wybór umiarkowanej wersji antropocentryzmu jako aksjologicznej podstawy rozwoju trwałego jest uzasadniony ${ }^{3}$. Takie podejście gwarantuje bowiem właściwy zakres odpowiedzialności, wyraźnie akcentuje nadrzędne miejsce człowieka na Ziemi, a jednoćześnie w imię sprawiedliwości wewnątrz- i międzypokoleniowej zapewnia należne poszanowanie środowiska przyrodniczego.

\section{Podsumowanie - konsekwencje zidentyfikowanych zależności dla pomiaru jakości życia}

Przeprowadzony przegląd literatury z zakresu rozwoju trwałego i analiza współczesnych uwarunkowań dotyczących jakości życia przyczyniły się do sformułowania wniosków, które stanowią etap w kierunku rozwiązania sformułowanego we wstępie problemu badawczego: jak łączyć pomiar wskaźnikowy jakości życia z pomiarem nowego paradygmatu rozwoju? Konkluzje, będące wynikiem zrealizowanych badań, a mające swoje konsekwencje dla pomiaru jakości życia, można zaprezentować następująco:

1. Rozwój trwały oznacza nie tylko dążenie do zaspokojenia materialnych potrzeb społeczeństwa, ale przede wszystkim do trwałego zapewnienia wysokiej jakości życia;

2. Zarówno rozwój trwały, jak i jakość życia są kategoriami mającymi holistyczny charakter i obejmuja co najmniej takie wymiary, jak: społeczny, środowiskowy i gospodarczy, a w najszerszym ujęciu również: przestrzenny, polityczno-instytucjonalny i moralno-etyczny;

3. Pomiędzy realizacją rozwoju trwałego a poprawą jakości życia występuje dodatnie sprzężenie zwrotne;

4. Omawiane kategorie opierają się na tej samej koncepcji potrzeb;

5. Podstawą aksjologiczną w każdym przypadku jest umiarkowany antropocentryzm.

Przeprowadzone badania pozwalają uznać za słuszną tezę, że oparcie pomiaru jakości życia na paradygmacie rozwoju trwałego jest uzasadnione i wykonalne. Przyjęcie takiego rozwiązania w następstwie umożliwia skonstruowanie syntetycznego wskaźnika lub wyselekcjonowanie zbioru wskaźników cząstkowych opisujących jakość życia, które będą stanowić godną uwagi alternatywę dla PKB w zakresie pomiaru dobrobytu społecznego.

\section{Literatura}

Borys T., 2001, Jakość zycia a zrównoważony rozwój. Relacje i pomiar, [w:] Ekonomia a rozwój zrównoważony. Teoria $i$ keształcenie, F. Piontek (red.), Wydawnictwo Ekonomia i Środowisko, Białystok.

Borys T., 2004, Pomiar trwałego i z̧ównoważonego rozwoju, [w:] Uwarunkowania i mechanizmy zrównoważonego roẓwoju, Wydawnictwo Wyższej Szkoły Ekonomicznej w Białymstoku, Białystok-Supraśl.

\footnotetext{
${ }^{3}$ Intensywne prace na ten temat były prowadzone już przed laty m.in. przez Tadeusza Borysa [Borys, 2004 s. 55-65; Borys, 2010, s. 57-76].
} 
Borys T., 2005, Zrównoważony roz̧wój jako pržedmiot pomiaru wskaźnikowego, [w:] Wskaźniki zrównoważonego roz̨oju, T. Borys (red.), Wydawnictwo Ekonomia i Środowisko, Warszawa-Białystok.

Borys T., 2010, Koncepcja zrównoważonego rozwoju w naukach ekonomicznych, [w:] Edukacja dla zrównoważonego rozwoju. Edukacja dla ładu ekonomicznego, B. Poskrobko (red.), Wydawnictwo Ekonomia i Środowisko, Białystok-Wrocław.

Borys T., 2014, Wybrane problemy metodologii pomiaru nowego paradygmatu rozwoju - polskie doświadczenia, „Optimum. Studia Ekonomiczne”, nr 3(69).

Brandle S., 2009, Wirtschaftsleistung falsch bewertet, Frankfurter Rundschau, http://www.fr-online.de/wirtschaft/statistik-wirtschaftsleistung-falsch-bewertet, 1472780,3278612.html (data wejścia: 15.08.2015).

Carlowitz H. C., 2009, Sylvicultura Oeconomica. Hausswirthliche Nachricht und Naturmäßige Anweisung zur Wilden Baum-Zucht, Reprint der zweiten Auflage von 1732, Verlag Kessel, Remagen-Oberwinter.

Costanza R., Hart M., Posner S., Talberth J., 2009, Beyond GDP: The Need for New Measures of Progress, Boston University, Boston.

Czaja S., 2011, Kategoria czasu w ekonomii zrównoważonego rozwoju oraz gospodarce opartej na wiedsy, [w:] Uwarunkowania rozwoju zrównoważonej gospodarki opartej na wiedzy, B. Poskrobko (red.), Wydawnictwo Wyższej Szkoły Ekonomicznej w Białymstoku, Białystok.

Daly H. E., Cobb J. B., 1989, For the Common Good: Redirecting the Economy Toward Community, the Environment, and a Sustainable Future, Beacon Press, Boston.

Famielec J., 2009, Wplyw idei zrównoważonego rozwoju na polityke państwa i funkcjonowanie przedsiębiorstw, [w:] Wplyw idei zrównoważonego rozwoju na polityke państwa i regionów, t. 1., Problemy ogólnopaństwowe $i$ sektorowe, B. Poskrobko (red.), Wydawnictwo Wyższej Szkoły Ekonomicznej w Białymstoku, Białystok.

Franciszek, 2015, Enc. Laudato Si, Wydawnictwo M, Kraków.

Galloway S., Bell D., Hamilton Ch., Scullion A., 2006, Quality of Life and Well-Being: Measuring the Benefits of Culture and Sport - A Literature Review, Scottish Executive Education Department, Edinburgh.

Glatzer W., 2006, Conditions and Criteria for Improving Quality of Life, [in:] Towards Quality of Life Improvement, W. Ostasiewicz (red.), The Publishing House of the Wrocław University of Economics, Wrocław.

Górka K., 2010, Kontrowersje terminologiczne w zakeresie ekonomiki ochrony środowiska i ekonomii ekologicznej, „Ekonomia i Środowisko”, nr 2(38).

Górka K., Luszczyk M., 2014, Rozwój trwały i zrównoważony w przestrzeni wirtualnej, [w:] Meandry wspólpracy sieciowej w Europie Środkowej $i$ Wschodniej, S. Partycki (red.), Wydawnictwo Katolickiego Uniwersytetu Lubelskiego, Lublin.

Hołub G., 2005, Człowiek w perspektywie bioetyki środowiskowej, „Analecta Cracoviensia”, nr XXXVII.

Hołub G., 2009, Gtęoke ekologia a idea jedności człowiek a zprayroda, [w:] Sacrum a príroda, G. Pala, P. Tirpak (red.), Wydawnictwo Papieskiej Akademii Teologicznej, Kraków. 
Janse A. J., Gemke R. J., Uiterwaal C. S., van der Tweel I., Kimpen J. L., Sinnema G., 2004, Quality of Life: Patients and Doctors Don't Always Agree: a Meta-Analysis, "Journal of Clinical Epidemiology", nr 7.

Jeżowski P., 2012, Rozwój zrównoważony i jego nowe ny zwania, „Kwartalnik Kolegium Ekonomiczno-Społecznego. Studia i Prace", nr 2.

Johannesburg Summit 2002. World Summit on Sustainable Development 26 August-4 September 2002, 2001, United Nations, New York.

Jonas H., 1996, Zasada odpowiedzialności, Platan, Kraków.

Kiełczewski D., 2013, Kapitat kulturowy jako przedmiot $i$ wyžwanie teorii zִónnoważonego rozwoju, „Handel Wewnętrzny”, listopad-grudzień.

Komunikat Komisji do Rady i Parlamentu Europejskiego. Wyjsć poza PKB. Pomiar postępu w żmieniajacym sie śniecie $\mathrm{KOM}(2009)$ 433, wersja ostateczna.

Komunikat Komisji. Zrównoważona Europa dla Lepszego Świata: Strategia Zrównoważonego Rozwoju Unii Europejskiej, $\mathrm{KOM}(2001)$ 264, wersja ostateczna.

Kusterka-Jefmańska M., 2010, Wysoka jakość sycia jako cel nadrzędny lokalnych strategii zrównoważonego rozwoju, „Zarządzanie Publiczne”, nr 4.

Łuszczyk M., 2013, Pomiar jakości sycia w skali międynnarodowej, Wydawnictwo Fundacji Uniwersytetu Ekonomicznego w Krakowie, Kraków.

Maslow A., 1943, A Theory of Human Motivation, „Psychological Review”, no. 50.

Measurement of National Income and the Construction of Social Accounts, Studies and Reports on Statistical Methods, 1947, United Nations, Geneva.

Noll H.-H., 2000, Konzepte der Wohlfahrtsentwicklung: Lebensqualität und "neue" Woblfahrtskonzepte, „Papers der Querschnittsgruppe Arbeit \& Ökologie“, nr P00-505.

Ostasiewicz W., 2013, Dobrobyt i jakość \&ycia: badania w Polsce i za granica, „Śląski Przegląd Statystyczny", nr 11 (17).

Our Common Future. Report of the World Commission on Environment and Development, United Nations, A/42/427, 1987, United Nations, New York.

Papuć E., 2011, Jakosíć sycia - definicje i sposoby jej ujmowania, „Current Problems of Psychiatry", nr 2.

Papuziński A., 2006, Filožficzne aspekty zrównoważonego roz̧woju - wprowadženie, „Problemy Ekorozwoju", nr 2.

Piontek F., 2007, Teoria rozwoju a personologiczna koncepcja teorii ekonomicznej, [w:] Zarzqdzanie rozwojem, aspekty spoteczne, ekonomiczne i ekologiczne, B. Piontek, F. Pionek (red.), Polskie Wydawnictwo Ekonomiczne, Warszawa.

Poskrobko B., 1998, Podstany polityki ekologičnej, [w:] Ochrona środowiska. Problemy spoteczne, ekonomiczne i prawne, K. Górka, B. Poskrobko, W. Radecki (red.), Polskie Wydawnictwo Ekonomiczne, Warszawa.

Problems of the Human Environment, A/RES/2398 (XXIII), 1969, [in:] Resolutions adopted by the General Assembly during its 23rd session. Supplement No. 18 (A/7218), United Nations, New York.

Report of the United Nations Conference on the Human Environment, A/CONF.48/14/Rev.1, 1972, United Nations, Stockholm. 
Rio Declaration on Environment and Development, The United Nations Conference on Environment and Development, A/CONF.151/26/Rev.1 (Vol. I), 1993, United Nations, New York.

Ro:porzadzenie Parlamentu Europejskiego i Rady (UE) nr 549/2013 z dnia 21 maja 2013 roku w sprawie europejskiego systemu rachunkón narodonych $i$ regionalnych w Unii Europejskiej, Dz. UE L174/2013.

Simonde de Sismondi J. C. L., 1955, Nowe zasady ekonomii politycznej, csylli o bogactwie i jego stosunku do ludności, Wydawnictwo Naukowe PWN, Warszawa.

Soziologie-Lexikon, 1991, G. Reinhold, S. Lamnek, H. Recker, R. Oldenbourg (red.), Verlag, München-Wien.

Stiglitz J. E., Sen A., Fitoussi J. P., 2013, Bład pomiaru. Dlaczego PKB nie nystarcza, Polskie Towarzystwo Ekonomiczne, Warszawa.

Szarfenberg R., 2011, Detronizacja PKB, „Nowy Obywatel”, nr 2.

Śleszyński J., 2011, Obrona syntetycznych wskaźnikón rozwoju trwatego, [w:] Ekonomia zrównoważonego rozpoju w swietle kanonów nauki, B. Poskrobko (red.), Wydawnictwo Wyższej Szkoły Ekonomicznej w Białymstoku, Białystok.

Żylicz T., 2007, Wskaźniki trwatego rozwoju: spojrzenie ekonomisty, „Prace Naukowe Akademii Ekonomicznej im. Oskara Langego we Wrocławiu”, nr 1190.

Żylicz T., 2010, Elementy teorii ұrównoważonego rozpoju, [w:] Wyžwania zrównoważonego rozwoju w Polsce, J. Kronenberg, T. Bergier (red.), Fundacja Sędzimira, Kraków.

Żylicz T., 2014, Cena prayrody, Wydawnictwo Ekonomia i Środowisko, Białystok. 